\title{
BIOKIMIAWI RIZOSFER BIBIT ROTAN PADA PEMUPUKAN NITROGEN DARI SUMBER BERBEDA
}

\author{
BIOCHEMICAL RHIZOSPHERE OF RATTAN'S SEEDLING UNDER \\ DIFFERENT NITROGEN FERTILIZATION
}

\author{
Lisa Indriani Bangkele ${ }^{1 *}$, Muhammad Basir $\mathrm{Chio}^{2}$, Aiyen Tjoa ${ }^{2}$, Andi Tanra Tellu ${ }^{3}$ \\ ${ }^{1}$ Program Studi Agroteknologi Universitas Alkhairaat Palu \\ Jl. Diponegoro No. 39 Palu 94221, Indonesia \\ ${ }^{2}$ Program Studi Agroteknologi Universitas Tadulako Palu \\ ${ }^{3}$ Program Studi Biologi Universitas Tadulako Palu \\ Jl. Soekarna Hatta Km 9 Palu 94118, Indonesia
}

\begin{abstract}
ABSTRAK
Interaksi akar dan tanah akan mengubah status biokimia rizosfer, akuisisi unsur hara dan berdampak pada pertumbuhan tanaman. Biokimia dari rhizosfer sangat dipengaruhi oleh input pertanian misalnya. pupuk, herbisida dan sistem manajemen pertanian. Pemberian pupuk, efeknya kuat dan sulit diukur. Pengaruh pemupukan terhadap status biokimia rhizosfer dan pertumbuhan tanaman berbeda-beda tergantung pada jenis pupuk, media tumbuh, jenis tanaman, serta kondisi lingkungan, sedangkan pengaruhnya terhadap tanaman akan spesifik untuk masing-masing tanaman. Penelitian ini mengkaji pengaruh input pupuk anorganik N dari dua sumber yaitu Urea (CO (NH2) 2) dan Amonium Sulfat atau ZA ((NH4) 2.SO4), dan metode pemupukan yang berbeda (homogen dan terlokalisasi). Percobaan menunjukkan aplikasi pupuk $\mathrm{N}$-Urea dan N-ZA menurunkan $\mathrm{pH}$ rhizosfer hingga 1,4 poin. Namun, keasaman rizosfer mengurangi koloni mikroorganisme dan laju respirasi.
\end{abstract}

Katakunci : biokimiawi rhizosfer, urea, amonium sulfat, koloni mikroorganisme, respirasi mikroorganisme

\begin{abstract}
Root and soil interactions will alter the biochemical status of the rhizosphere, the acquisition of nutrients and impacted to plant growth. The biochemical of the rhizosphere is strongly influenced by the agriculture input e.g. fertilizer, herbicides and farm management system. Application of fertilizers, their effects are robust and difficult tobe quantified. The effect of fertilizer on the biochemical status rhizosphere and plant growth is different depending on the type of fertilizers, growth media, plant species, and also the environment condition, while the effect on plants will be specific to each plant. This research investigated on the effect of $N$ inorganic fertilizer inputs from two sources namely Urea $(\mathrm{CO}(\mathrm{NH} 2) 2)$ and Ammonium Sulfate or ZA ((NH4)2.SO4), and different fertilization method (homogenous and localized). Experiments showed application of $N$-Urea and $N$-ZA fertilizers reduced the rhizosphere $\mathrm{pH}$ until 1,4 point. However, acidity of the rhizosphere reduced microorganism colonies and respiration rate.
\end{abstract}

Keywords: Rhizosphere biochemical, Urea, Ammonium Sulphate, microorganism colony, microorganism respiration.

\section{Pendahuluan}

Secara umum pertumbuhan tanaman berkorelasi positif dengan pemberian input

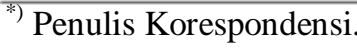

E-mail: lisaindriani@unisapalu.ac.id

Telp: +62-813303196095
}

(pupuk, pestisida, termasuk manajemen pertanaman), tetapi tinggi atau rendahnya korelasi ini dipengarungi oleh beragam faktor, baik yang pendukung maupun faktor penghambat. Pemberian input pertanian seperti pupuk memberi pengaruh besar terhadap kondisi daerah perakaran dan respons akar. Input yang diberikan kepada tanaman akan direspons oleh 
dan pengaruhnya dapat diselidiki dan diukur. Pengaruh pupuk tersebut berbeda tergantung kepada jenis pupuk, jenis media tumbuh, jenis tanaman, dan juga lingkungan.

Teknik pemupukan akan memberi pengaruh berbeda pada rizosfer dan pertumbuhan tanaman. Teknik pemupukan terlokalisasi pada beberapa penelitian dilaporkan menyebabkan stres fisiologi pada tanaman, namun pada beberapa tanaman dapat meningkatkan produktivitas tanaman yang lebih baik sebagai akibat dari adaptasi fisiologisnya (Graciano, dkk., 2009; Ma, dkk., 2013; McNear, 2013). Pemupukan terlokalisasi mempunyai korelasi yang tinggi dengan tanaman tahunan seperti rotan. Bahan organik atau nutrisi di dalam hutan biasanya terkumulasi pada lapisan atas (Wei, dkk., 2011; Worrel dan Hampson, 1997).

Pemupukan N, P, K sangat meningkatkan eksudat akar, biomassa dan keragaman (diversity) mikroorganisme tanah (Hu, dkk., 2011). Akuisisi ion dapat terus berlangsung oleh pertukaran elektron yang menetralisir ion dalam tubuh tanaman (Yruela, 2009; Foyer, dkk., 2012). Hal ini dapat terjadi dengan adanya hidrogen, bikarbonat atau hidroksil. Ion dapat dilepaskan jika ada akses akuisisi kation atau anion. PH larutan di luar akar akan meningkat jika ada lebih banyak anion dibanding kation (untuk valensi yang sama) yang diserap, dan menurun jika lebih banyak kation diserap (Gregory, 1999). Sebagai contoh, jika N diserap sebagai nitrat $\left(\mathrm{NO}_{3}\right)$, maka anion yang diserap, dan $\mathrm{pH}$ diluar akar akan meningkat, dan jika yang diserap adalah amonium $\left(\mathrm{NH}_{4}{ }^{+}\right)$maka $\mathrm{pH}$ akan menurun. Perubahan $\mathrm{pH}$ pada rizosfer juga Tabel 1. Desain Penelitian mempunyai konsekuensi yang penting untuk akuisisi P (Gregory, 1999; Marschner, 1995; Hinsinger, 2001), akuisisi $\mathrm{Cd}$ dan $\mathrm{Zn}$ oleh T.caerulescens (Xie, dkk., 2009), akuisisi $\mathrm{Cu}$ oleh tanaman tomat dan oilseed rape pada tanah masam (Chaignon, dkk., 2002)

Rotan merupakan salah satu tanaman hutan yang penting secara ekonomi di Indonesia. Indonesia sebagai penghasil dan pemasok utama rotan dunia, sebagian besar rotan Indonesia hanya mengandalkan sumber rotan alam, sehingga menyebabkan terus berkurangnya potensi produksi rotan Indonesia.

Penelitian ini ditujukan untuk melihat perubahan biokimiawi rizosfer akibat pemupukan. Pengetahuan yang dihasilkan dari mempelajari interaksi akar dan media tumbuh pada tanaman rotan akan memberikan nilai ilmiah penting baik bagi konservasi plasma nutfah rotan maupun kelestarian rotan untuk industri.

\section{Metode Penelitian}

Penelitian II menggunakan rancangan acak kelompok (RAK) dengan 2 faktor. Perlakuan diulang sebanyak 4 (empat) kali, sehingga diperoleh $3 \times 2 \times 4=24$ unit perlakuan. Pengacakan dilakukan menurut cara yang dikembangkan Gomez dan Gomez (1984).

Untuk menguji pengaruh perlakuan yang dicobakan dilakukan Analisis Varians. Hasil analisis yang menunjukkan pengaruh nyata dilanjutkan dengan uji lanjut Beda Nyata Terkecil (BNT) taraf 0,05 untuk menentukan perbedaan antar perlakuan, interaksi, dan perlakuan yang terbaik.

\begin{tabular}{llcc}
\hline \multirow{2}{*}{ No } & Faktor II & \multicolumn{2}{c}{ Faktor I } \\
\cline { 3 - 4 } & & $\begin{array}{c}\text { Pemupukan Homogen } \\
(\mathrm{H})\end{array}$ & $\begin{array}{c}\text { Pemupukan } \\
\text { Terlokalisasi(L) }\end{array}$ \\
\hline 1 & Kontrol $(\mathrm{K})$ & HK & LK \\
\hline 2 & N Urea;100kg N/Ha+P SP36; 50kg P/Ha (NU) & HNU & LNU \\
\hline 3 & N ZA;100kg N/Ha+P SP36; 50kg P/Ha (NZA) & HNZA & LNZA \\
\hline
\end{tabular}

\section{Bahan dan Alat}

Alat yang digunakan pada penelitian pada rizoboks terdiri dari acrilyc; tri huk; baut; bor; plastik hitam; plastik transparan (OHP); timbangan analitik; $\mathrm{pH}$ meter; hands prayer; gelas ukur; pipet berskala; toples kaca berpenutup.

Bahan yang digunakan dalam penelitian pada rizoboks terdiri dari tanah dari Hutan Desa Sejahtera Palolo Sulawesi Tengah, pH 5,4 (pH
Aquades); anorganik Nitrogen (Urea dan Amonium Sulfat (ZA)); anorganik Fosfor (SP36); anorganik Kalium $(\mathrm{KCl})$; bibit rotan varietas Noko (Daemonorops sp.) umur 8 minggu semai; soda lime; $\mathrm{HCl} ; \mathrm{NaOH} ; \mathrm{H}_{2} \mathrm{SO}_{4} ; \mathrm{pH}$ buffer 4, 7 dan 9; purple bromochresole; kertas tissue; kain kasa, filter paper; aquadest.

\section{Prosedur Pelaksanaan Penelitian pada Rizoboks}


Rizoboks diisi tanah hingga setinggi $25 \mathrm{~cm}$ dengan demikian sehingga tanah yang diperlukan untuk setiap rizoboks adalah $1,200 \mathrm{~kg}$ tanah $(25$ $\mathrm{cm} \times 16 \mathrm{~cm} \times 2,5 \mathrm{~cm} \times 1,20 \mathrm{~g} \mathrm{~cm}^{-3}$ ). Pengisian tanah ke dalam rizoboks diusahakan dengan kerapatan tanah yang seragam $\left(1,20 \mathrm{~g} \mathrm{~cm}^{-3}\right)$. Bibit rotan dipindahkan secara hati-hati ke dalam rhizoboks dengan posisi akar pada permukaan. Rizoboks dibungkus dengan plastik hitam tebal dan kemudian diletakkan pada posisi miring $45^{\circ}$.

\section{Hasil dan Pembahasan}

\section{Hasil}
1. Perubahan Biokimiawi Rizosfer Akibat perlakuan Pupuk N-Urea atau N-ZA, dan Teknik Pemupukan Homogen atau Terlokalisasi

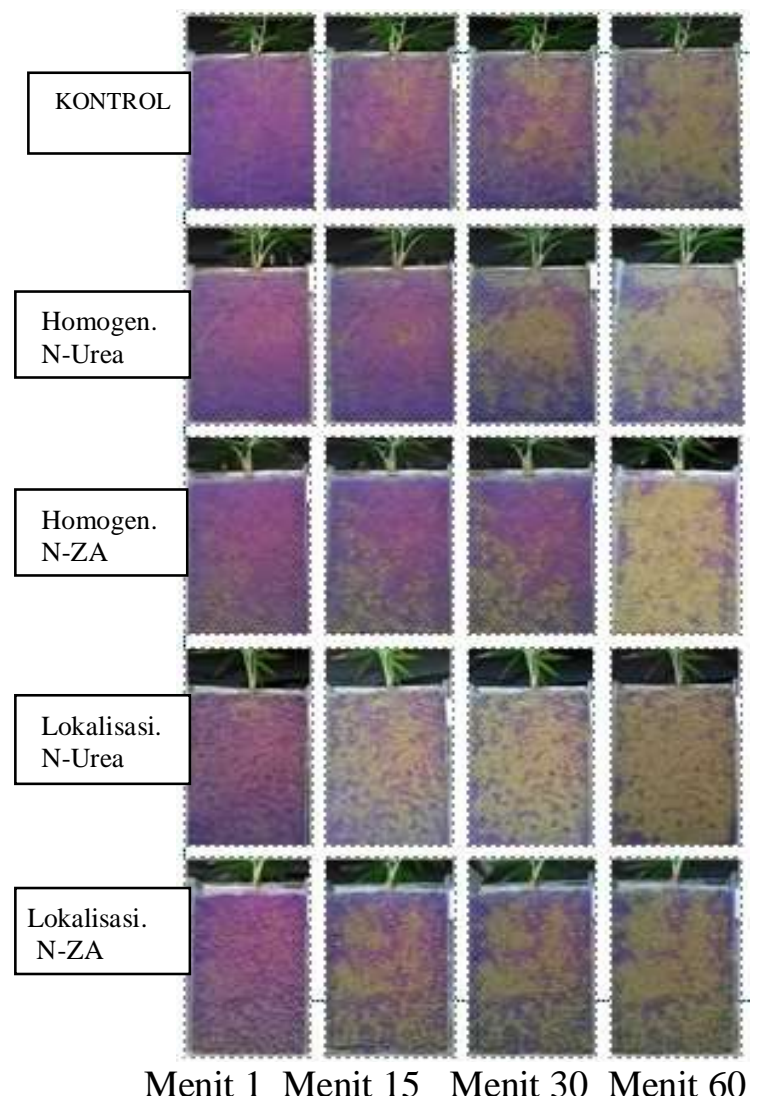

Gambar 1 (a) Perubahan Warna Agar Blok Rizosfer pada Menit Pertama (Menit ke-1) Menit ke-15, Menit ke-30, Menit ke60 pada Perlakuan Pupuk N Berbeda (N-Urea atan N-ZA) dan Teknik Pemupukan Homogen dan Terlokalisasi.

Beberapa penelitian menunjukan $\mathrm{pH}$ rizosfer berubah akibat input yang diberikan dan oleh aktivitas mikroorganisme. PH tanah (rizosfer dan bulk) pada penelitian ini dianalisis menggunakan agar yang ditambahkan indikator warna bromokresol ungu (purple bromochresol) yang telah diuji sensitivitasnya terhadap perubahan $\mathrm{pH}$ permukaan tanah. Warna ungu agar blok menunjukkan $\mathrm{pH}$ netral, dan makin rendah $\mathrm{pH}$ rizosfer maka makin kuning warga agar blok.

Pada penelitian ini pengamatan pada menit pertama menunjukkan perubahan warna dimulai pada agar yang kontak langsung dengan akar bibit rotan. Pada menit ke-15 dan menit ke-30 telah menunjukkan adanya perubahan warna yang jelas pada daerah sekitar akar. Pada pengamatan menit ke 60 , perubahan warna agar menjadi kuning hampir di seluruh permukaan tanah pada jendela rizoboks. Kondisi ters semua perlakuan menunjukkan bahwa pemasaman tidak hanya terjadi di sekitar akar (rizosfer), namun pada daerah eksklusif yang masih dipengaruhi akar tanaman. Warna agar lebih kuning pada perlakuan N-ZA dibandingkan kontrol dan $\mathrm{N}$ Urea, menunjukkan N-ZA menyebabkan $\mathrm{pH}$ rizosfer lebih rendah ( $\mathrm{pH} 4,0-4,2)$ dibandingkan N-Urea (pH 4,2) (Gambar 1(a)).

Rekapitulasi $\mathrm{pH}$ rizosfer disajikan pada Gambar 1(b)) menunjukkan bahwa pada menit pertama $\mathrm{pH}$ perlakuan $\mathrm{N}$-Urea secara homogen lebih rendah $(4,6)$ dibandingkan perlakuan lain $(\mathrm{pH} 4,8)$. Namun pada akhir pengamatan yaitu pada menit ke 60 terlihat bahwa $\mathrm{pH}$ perlakuan $\mathrm{N}$ ZA lebih rendah berkisar di $\mathrm{pH} 4$, sedangkan perlakuan $\mathrm{N}$-Urea maupun kontrol $\mathrm{pH}$ rizosfer sekitar 4,2.

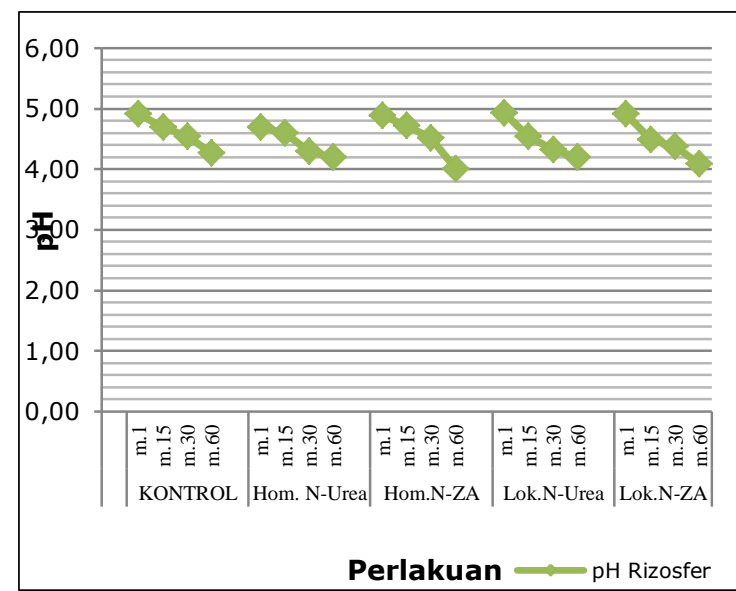

Gambar 1 (b). Rekapitulasi pH Rizosfer pada Menit Pertama (Menit ke-1), Menit ke-15, Menit ke-30, Menit ke-60 pada Perlakuan Pupuk N Berbeda (NUrea atan N-ZA) dan Teknik 
Jurnal Agratech 10 (1) 15-20, Juni 2020

Pemupukan Homogen dan
Terlokalisasi.

2. Jumlah Koloni dan Respirasi Mikroorganisme Akibat Pemberian Pupuk N-Urea atau N-ZA, dan Teknik Pemupukan Homogen atau Terlokalisasi.

Gambar 4.20 memperlihatkan $\mathrm{pH}$ rizosfer dan jumlah koloni mikroorganisme perlakuan $\mathrm{N}$ ZA dengan pemupukan homogen paling rendah, dan $\mathrm{pH}$ serta jumlah koloni mikroorganisme tertinggi ada perlakuan kontrol. Hasil penelitian juga mendapatkan jumlah koloni mikroorganisme perlakuan dengan pemupukan terlokalisasi lebih tinggi dibandingkan pemupukan homogen.

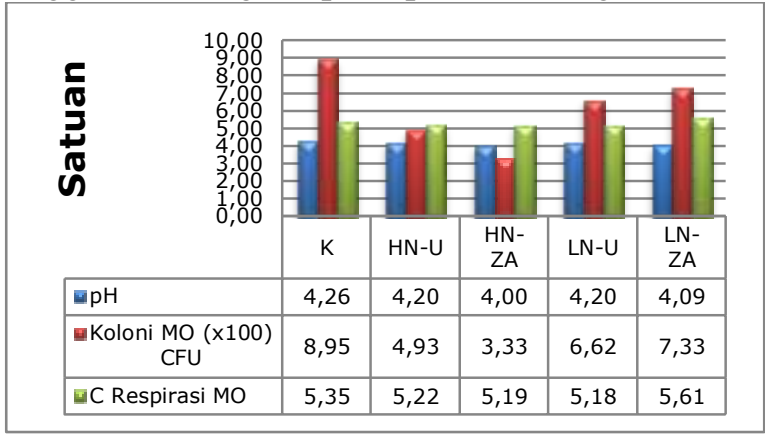

Gambar 2. pH Rizosfer, Koloni Mikroorganisme (MO) (x100) CFU, Karbon (C) Respirasi (mg.100 ${ }^{-1}$ g tanah) pada Perlakuan Kontrol, Homogen N-Urea, Homogen N-ZA, Lokalisasi N-Urea, dan Lokalisasi N-ZA

\section{Hubungan pH dengan Jumlah Koloni dan Respirasi Mikroorganisme}

Perubahan $\mathrm{pH}$ akibat pemupukan mempengaruhi jumlah (CFU) koloni mikroorganisme. $\mathrm{pH}$ rizosfer akan menetukan koloni mikroorganisme dominan, melalui proses seleksi alam, hanya mikroorganisme yang toleran terhadap $\mathrm{pH}$ dari rizosfer yang dapat bertahan hidup dan merupakan koloni dominan yang akan mempengaruhi reaksi biokimia di dalam rizosfer.

Korelasi antara pH dengan koloni mikroorganisme (CFU) pada penelitian ini diuji dengan Uji Korelasi Pearson menggunakan Mini Tab. Hasil analisi memperlihatkan variabel $\mathrm{pH}$ memiliki korelasi negatif yang kuat $\quad(\mathrm{R}=$ $0,683)$ dengan variabel koloni mikroorganisme. Artinya penurunan jumlah koloni mikroorganisme memiliki korelasi yang kuat dengan kenaikan $\mathrm{pH}$.

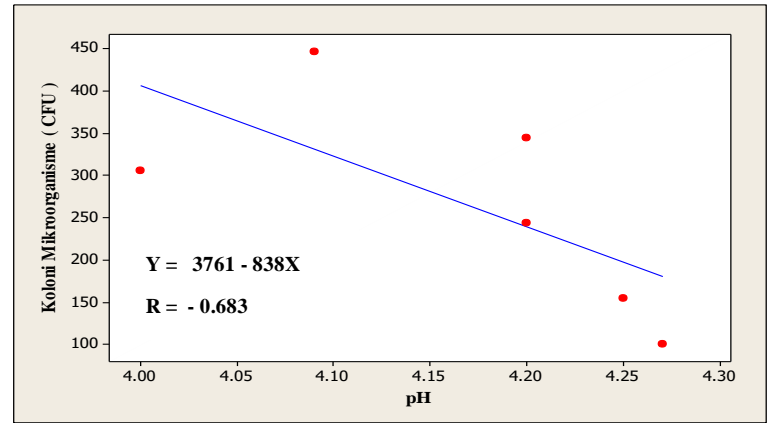

Gambar 3. Regresi antara pH Rizosfer dengan Koloni Mikroorganisme (CFU) pada Perlakuan Kontrol, Homogen N-Urea, Homogen NZA, Lokalisasi N-Urea, dan Lokalisasi NZA

Korelasi antara $\mathrm{pH}$ dengan Karbon (C) respirasi mikroorganisme $(\mathrm{g})$ pada penelitian ini diuji dengan Uji Korelasi Pearson menggunakan Mini Tab. Hasil analisi memperlihatkan variabel luas akar memiliki korelasi negatif yang sangat lemah $(\mathrm{R}=-0,021)$ dengan variabel biomassa akar. Hubungan $\mathrm{pH}$ rizosfer dengan $\mathrm{C}$ respirasi miroorgamisme mendekati nol (0) atau dapat diabaikan.

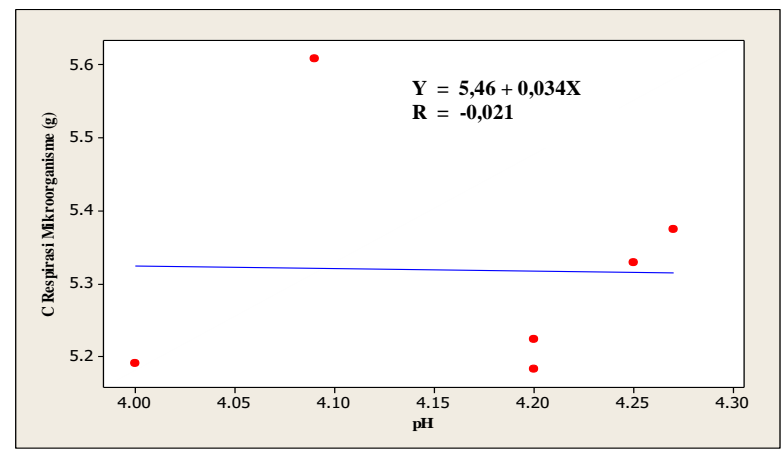

Gambar 4. Regresi antara pH Rizosfer dengan Karbon (C) Respirasi Mikroorganisme (g 100-1 tanah) pada Perlakuan Kontrol, Homogen N-Urea, Homogen N-ZA, Lokalisasi NUrea, dan Lokalisasi N-ZA

\section{Pembahasan}

\section{Perubahan Biokimiawi Rizosfer pada Penelitian pada Pot}

Pada penelitian ini input anorganik $\mathrm{N}(\mathrm{N}$ Urea atau N-ZA) menurunkan $\mathrm{pH}$ rizosfer. Hasil tersebut menunjukkan N-Urea dan N-ZA bereaksi memasamkan tanah. Pada penelitian ini menjelaskan bahwa N-Urea dan N-ZA di dalam tanah lebih banyak terhidrolisis menjadi ion $\mathrm{NH}_{4}{ }^{+}$yang pada proses pertukaran antar ion menyebakan lebih banyak ion $\mathrm{H}^{+}$dan asam dapat tukar lainnya ke luar dari kompleks jerapan. 


\section{Jurnal Cgratech 10 (1) 15-20, Juni 2020}

Selain itu akar bibit rotan tidak mampu mengeluarkan anion $\left(\mathrm{NO}_{3}{ }^{-}\right)$untuk menetralisir kemasaman rizosfer, yang terjadi adalah pertukaran kation dari/ke akar menyebabkan keluarnya kation atau $\mathrm{H}+$ dari dalam akar kemudian masuk ke larutan tanah sehingga menyebabkan $\mathrm{pH}$ rizosfer menjadi lebih masam. Sejalan dengan penelitian Zhang, dkk. (2004), bahwa penurunan $\mathrm{pH}$ tanah dapat terjadi pada aplikasi pupuk $\mathrm{N}$ dalam bentuk $\mathrm{NH}_{4}{ }^{+}$.

Perlakuan N-ZA menyebabkan penurunan $\mathrm{pH}$ yang lebih besar dibandingkan N-Urea. Ion sulfat yang dihasilkan dari pupuk ZA mudah larut dan bereaksi dengan anion di dalam larutan tanah ikut menurunkan $\mathrm{pH}$ rizosfer, sehingga menyebabkan $\mathrm{pH}$ rizosfer lebih rendah pada perlakuan dengan N-ZA dibandingkan perlakuan N-Urea.

Hasil penelitian menunjukkan $\mathrm{pH}$ rizosfer bersifat masam. Perlakuan pupuk $\mathrm{N}$ menurunkan $\mathrm{pH}$ rizosfer menjadi masam bahkan sangat masam (pH 4.2 dengan $\mathrm{N}$-Urea dan hingga 4.0 dengan N-ZA) pada rizosfer. Pada penelitian ini $\mathrm{pH}$ yang sangat masam merubah biologi rizosfer, antara lain mempengaruhi jumlah koloni dan aktivitas respirasi mikroorganisme. Struktur dari komunitas bakteri berhubungan dengan eksudat akar dan kimiawi rizosfer (Cheng, dkk., 2016). Pada $\mathrm{pH}$ tanah 4,5 atau lebih rendah, populasi bakteri akan menurun dan populasi jamur akan meningkat (Rousk, dkk., 2009).

Jumlah dan aktivitas respirasi mikroorganisme dipengaruhi dan mempengaruhi $\mathrm{pH}$ tanah. Pada penelitian ini, penurunan $\mathrm{pH}$ tanah akibat pemupukan $\mathrm{N}$ menekan aktivitas respirasi mikroorganisme. Hasil uji korelasi Pearson menunjukkan korelasi positif sangat lemah $(\mathrm{R}=0,208)$ antara $\mathrm{pH}$ dengan respirasi mikroorganisme. Hasil penelitian ini sejalan dengan hasil penelitian Syahputra (2009) bahwa $\mathrm{pH}$ mempengaruhi aktivitas respirasi mikroorganisme, akan tetapi respirasi mikroorganisme sangat rendah pada $\mathrm{pH}$ tanah di bawah 4,5 dibandingkan respirasi pada $\mathrm{pH}$ tanah 5-8 (Rousk, dkk., 2009).

\section{Kesimpulan}

Perlakuan N (N-Urea ataupun N-ZA) pada bibit rotan menurunkan $\mathrm{pH}$ rizosfer. Implikasinya adalah media tanah yang digunakan untuk pembibitan rotan harus netral untuk mencegah penurunan $\mathrm{pH}$ disekitar rizosfer akibat pengunaan pupuk $\mathrm{N}$ - Urea maupun N-ZA.
e-ISSN : 2621-7236

p-ISSN : 1858-134X

\section{Daftar Pustaka}

Agustiyani, D., Imamuddin, H., Farida, E., Oedjijono. 2004. Pengaruh pH dan Substrat Organik terhadap Pertumbuhan dan Aktivitas Bakteri Pengoksidasi Amonia. Biodiversitas. 5(2): 43-47.

Bagus, R. U. I. G. 2016. Uji Korelasi. Ebook. DOI: 10.13140/RG.2.25690.

Chaignon, V., F. Bedin, dan Philippe Hinsinger. 2002. Copper Bioavailability dan Rhizosphere PH Changes as Affected by Nitrogen Supply for Tomato and Oilseed Rape Cropped on an Acidic and a Calcareous Soil. Plant and Soil 243(2): 21928.

Cheng, Y., Jiang, Y., Wu, Y., Valentine, T.A. dan Li, H. 2016. Soil Nitrogen status Modifies Rice Root Response to NematodeBacteria Interactions in the Rhizosphere . PLOS one. 10(137): 1-19.

Dransfield, J. 1979. A Manual of the Rattans of the Malay Peninsula. Forest Department, Ministry of Primary Industries Malaysia.

Foyer, C.H., Neukermans, J., Queval, G., Noctor, G. dan Harbinson, J. 2012. Photosyntetic Control of Electron Transport and the Regulation of Gene Expression. Journal of experimental Botani. 63(4): 1637-1661.

Graciano, C., Tambussi, E.A., Castan, E. dan Guiamet. J.J. 2009. Dry Mass Partitioning and Nitrogen uptake by Eucalyptus grandis Plants in Response to Localized or Mixed Application of Phosphorus. Plant Soil. 319: 175-184.

Gregory, P. J., dan Hinsinger, P. 1999. New Approaches to Studying Chemical and Physical Changes in the Rhizosphere: An Overview. Plant and Soil 211(1): 1-9.

Gomez, K.A., Gomez, A.A. 1984. Statistical Procedures for Agricultural.Second Edition. An International Rice Research institute Book. A Wiley-Interscience publication. John Wiley \& Sons. New York.

Hinsinger, P. 2001. Bioavailability of Soil Inorganic $\mathrm{P}$ in the Rhizosphere as Affected by Root-Induced Chemical Changes: A Review. Plant and Soil. 237(2): 173-95.

Hu, J., Lin, X., Wang, J., Dai, J., Chen, R., Zhang, J., Wong, M.H. 2011. Microbial 
Jurnal Agratech 10 (1) 15-20, Juni 2020

Functional Diversity, Metabolic Quotient, and Invertase Activity of a Sandy Loam Soil as Affected by Long-Term Application of Organic Amendment and Mineral Fertilizer. Journal of Soils and Sediments. 11(2): 27180.

Kaczmarkowa, W.W., ..., Pedziwilk. 2000. The Development of Fungi as Affected by $\mathrm{pH}$ and Type of Soil, in Relation to the Occurence of Bacteria and Soil Fungistatic Activity. Microbiological Research. 155(2): 107-112.

Kalima, T. dan Prameswari, D. 2017. Karakteristik Jenis Andalan Setempat Rotan di kabupaten Donggala, Provinsi Sulawesi Tengah. Buletin Plasma Nutfah. 23(2): 119126

Ma, Q., Zhang, F., Renge, Z. dan Shen, J. 2013. Localized Application of $\mathrm{NH}^{+}{ }^{-} \mathrm{N}$ Plus $\mathrm{P}$ and Later Growth Stages Enhances Nutrient Uptake and Maize Yield by Inducing Lateral Root Poliferation. Plant Soil. 372:65-80.

McNear Jr., D.H. 2013. The Rhizosphere- Roots, Soil and Everything in Between. Soil, Agricultur, Agricultural and Biotechnology. Nature Education Knowledge. 4(3):1.

Pinton, R., Varanini, Z. dan Nannipieri, P. 2001. The Rhizosphere. Biochemistry and Organic Substances at Soil-Plant Interface. Marcel Dekker,Inc. New York.

Rousk, J., Brookes, P. C., Baath, E. 2009. Contrasting Soil $\mathrm{pH}$ Effects on Fungal and Bacterial Growth Suggest Functional
e-ISSN : 2621-7236

p-ISSN : 1858-134X

Redundancy in Carbon Mineralization. Applied and Environmental Microbiology. American Society for Microbiology. 15891596. DOI: 10.1128/AEM.02775-08.

Wei, X., Li, Q., Waterhouse, M.J., Armleder, H.M. 2012. Organic Matter Loading Affects Lodgepole Pine Seedling Growth. Environmental, Management. 49(6): 11431149.

Widyawati, E. 2013. Dinamika Komunitas Mikroba di Rizosfer dan Kontribusinya Terhadap Tanaman Hutan. Tekno Hutan Tanaman. 6(2): 55-64.

Worrel, R. dan Hampson, A. 1997. The Influence of some Forest Operations on the Sustainable Management of Forest Soils-a Review. Forestry: An International Journal of Forest Research. 70(1). 61-85.

Xie, H. L., Jiang, R. F. dan Zhang, F. S. 2009. Effect of Nitrogen on the Rhizosphere Dynamics and Up Take of Cadmium and Zinc by the Hyperaccumulator Thlaspi caerulescens. Plant Soil. 318: 205-215.

Yruela, I. 2009. Copper in Plants: Acquisition, Transport and Interactions. Functional Plant Biology. 36: 409-430.

Zhang, F., Kang, S., Zhang, J., Zhang, R. dan Li, F. 2004. Nitrogen Fertilization on Uptake of Soil Inorganic Phosphorus Fractions in the Wheat Root Zone. Soil Science Society of America Journal. 68(6): 1890. 